\section{Random Amplified Polymorphic DNA Markers in Sweetpotato Infected with Fusarium lateritium}

\author{
Frank A. Buffone and Don R. La Bonte \\ Department of Horticulture, Louisiana State University Agricultural Center, \\ Louisiana Agricultural Experiment Station, Baton Rouge, LA 70803-2120
}

Christopher A. Clark

Department of Plant Pathology and Crop Physiology, Louisiana State University Agricultural Center, Louisiana Agricultural Experiment Station, Baton Rouge, LA 70803-1720

Additional index words. Ipomoea batatas, sweetpotato chlorotic leaf distortion, chlorotic leaf distortion, molecular markers

\begin{abstract}
DNA isolated from Fusarium lateritium Nees: Fr.-infected 'Jewel' sweetpotato [Ipomoea batatas (L.) Lam.] plants was compared to $F$. lateritium-free 'Jewel' plants for differences in random amplified polymorphic DNA (RAPD) marker products. Differences in RAPD marker products were detected. Amplified DNA isolations from F. lateritiuminfected 'Jewel' plants generated additional, unique DNA fragments not found in amplified DNA isolations of $F$. lateritium-free 'Jewel' plants. These unique amplified DNA fragments were consistent with those obtained from amplified DNA isolations of the $F$. lateritium isolate, 91-27-2, used for inoculation. We found that $F$. lateritium DNA successfully competes with sweetpotato DNA in the polymerase chain reaction for priming sites in a $3: 1$ ratio of sweetpotato DNA to $F$. lateritium DNA. Our results indicate the importance of avoiding plant material infested with pathogens to avoid spurious marker bands.
\end{abstract}

Random Amplified Polymorphic DNA (RAPD) markers are routinely used to construct linkage maps (Yu et al., 1993) and assess genetic diversity and systematic relationships (Jarret and Austin, 1994; Wachira et al., 1995) in a wide array of species. Additionally, DNA-based markers are widely suggested as means of unambiguously identifying cultivars for proprietary descriptions (Jondle, 1992; Rongwen et al., 1995) and, recently, determining the purity of hybrid seed (Paran et al., 1995). The RAPD technique has supplanted RFLP and isozyme techniques in many of these applications because of its lower cost, technical simplicity, high level of polymorphisms (Weeden et al. 1992), and low DNA template requirements.

Most researchers typically assume that any foreign microorganism's DNA present on in situ plants competes poorly for priming sites (Williams et al., 1993) or will be quantitatively low and will not appreciably amplify

Received for publication 14 Sept. 1995. Accepted for publication 18 July 1996. Approved for publication by the Director of the Louisiana Agricultural Experiment Station as manuscript no. 95-28-9222. The research was supported by funds from the International Potato Center, Lima, Peru, the Louisiana Sweet Potato Advertising and Developmen Commission, and by state and matching funds allocated to the Louisiana State Univ. Agricultural Center. The cost of publishing this paper was defrayed in part by the payment of page charges. Under postal regulations, this paper therefore must be hereby marked advertisement solely to indicate this fact. in bp. mericlones.

"Isolate 91-27-2. along with those of sweetpotato infected with this disease, commonly known as chlorotic leaf distortion (CLD) (Clark et al., 1990).

\section{Materials and Methods}

Indexed (Moyer et al., 1989), meristem-tip cultured 'Jewel' explants free of $F$. lateritium and sweetpotato feathery mottle virus were grown in a screenhouse. A portion of these explants were inoculated with a suspension of $1.0 \times 10^{6}$ macroconidia and microconidia of $F$. lateritium isolate 91-27-2. Mild chlorotic leaf distortion (CLD) symptoms, i.e., white fungal hyphae along leaf margins and mild chlorosis on the youngest terminal leaf, were observed beginning 5-7 weeks after inoculation. Three to four terminal, opened leaves were then removed from each infected plant and from isolated plants free of $F$. lateritium. Terminal leaves also were harvested from field-grown 'Jewel' clones naturally infected with $F$. lateritium.; symptoms on these were more severe than on greenhouse material, with chlorosis extending to three to four terminal opened leaves.

Total DNA from $\approx 2 \mathrm{~g}$ of freeze-dried leaf tissue from each sample plant was isolated based on the method of Saghai-Maroof et al. (1984) as modified by Jarret and Austin (1994). Conditions for DNA amplification using polymerase chain reaction (PCR) and electrophoresis have been reported by Villordon and $\mathrm{La}$ Bonte (1995). All RAPD primers that produced amplified DNA fragments were retested for reproducibility. Only intense staining bands were scored.

Fusarium lateritium isolate 91-27-2 was

Table 1. Effect of Fusarium lateritium infection on the occurrence of RAPD markers in 'Jewel' sweetpotato.

\begin{tabular}{|c|c|c|c|c|}
\hline \multirow[b]{2}{*}{ DNA marker $^{y}$} & \multicolumn{4}{|c|}{ Amplified DNA product $^{2}$} \\
\hline & CLD+ in situ Jewel ${ }^{\mathrm{x}}$ & CLD- Jewel & CLD+ Jewel & $\begin{array}{l}\text { Fusarium } \\
\text { lateritium }^{\mathrm{w}}\end{array}$ \\
\hline$\overline{\mathrm{F} 12-2127}$ & + & - & + & + \\
\hline F12-1878 & + & - & + & + \\
\hline F12-1085 & - & - & - & + \\
\hline F12-898 & + & + & + & - \\
\hline F12-788 & + & + & + & - \\
\hline F12-640 & + & + & + & - \\
\hline F1-1549 & + & + & + & - \\
\hline F1-1468 & - & - & - & + \\
\hline F1-1391 & + & + & + & - \\
\hline F1-1186 & + & + & + & _- \\
\hline F1-1066 & + & - & + & + \\
\hline F1-957 & - & - & - & + \\
\hline F1-857 & + & - & + & + \\
\hline F1-643 & + & + & + & - \\
\hline F1-405 & + & + & + & - \\
\hline A16-2896 & + & - & + & + \\
\hline A16-1925 & - & - & - & + \\
\hline A16-1634 & + & - & + & + \\
\hline A16-1468 & - & - & - & + \\
\hline A16-1392 & + & + & + & - \\
\hline A16-1125 & + & + & + & - \\
\hline A16-436 & + & + & + & - \\
\hline
\end{tabular}

${ }^{2}+$ Presence of amplified DNA product; - absence of amplified DNA product.

yProvisional marker designation represents Operon primer kit designation plus the estimated fragment size

${ }^{\times} \mathrm{CLD}+$ chlorotic leaf distortion affected, CLD- chlorotic leaf distortion free; in situ Jewel represents a 'Jewel' clone naturally infected under field conditions, CLD+ and CLD- Jewel represent greenhouse grown 
cultured at $28{ }^{\circ} \mathrm{C}$ in potato dextrose broth (PDB) on a shaker set at $200 \mathrm{rpm}$. for 1 week before vacuum filtration on Whatman \#1 filter paper. Total DNA was extracted, as before, from mycelium and bud cells weighing $\approx 0.5 \mathrm{~g}$. Reaction volumes for $F$. lateritium DNA were adjusted to $40 \mathrm{ng} / 25 \mu \mathrm{l}$. Amplification and electrophoresis conditions were the same as for plant DNA.

\section{Results and Discussion}

Three 10-mer oligonucleotide primers, OPA16, OPF1, and OPF12 (Operon Technologies, Alameda, Calif.), respectively, amplified 3, 5, and 3 DNA fragments in the PCR mixture of DNA isolated from $F$. lateritiumfree 'Jewel' plants. These fragments were consistent with those observed in previous studies with 'Jewel' (Villordon and La Bonte, 1995). Utilization of DNA isolated from $F$. lateritium-infected 'Jewel' plants in the PCR mixtures resulted in the amplification of unique DNA fragments not present when the template DNA was isolated from $F$. lateritium-free 'Jewel' plants (Table 1). These amplified DNA fragments were identical to those generated from the $F$. lateritium template DNA. Three additional primers, out of 35 originally screened, amplified faint DNA fragments that fit the same general banding pattern (data not shown). DNA fragments amplified by PCR from field-grown 'Jewel' infected with naturally-occurring $F$. lateritium were indentical to those from inoculated 'Jewel' (Table 1). This result demonstrates that our results were not merely artifacts of greenhouse conditions.

Preliminary studies showed that $F$. lateritium DNA template concentrations as low as $10 \mathrm{ng} / 25 \mu \mathrm{l}$ of reaction volume were sufficient to generate amplification products after 40 cycles of PCR. Our results indicate that $F$. lateritium DNA reaches concentrations that approach or exceed this amount in infected sweetpotato DNA isolations adjusted to $40 \mathrm{ng}$ of total DNA/25 $\mu \mathrm{l}$ of reaction volume; however, amplifications at lower DNA template concentrations are possible if many highand middle-repetitive sequences are present or perfect inverted repeats exist in the $F$. lateritium genome. We also found that $F$. lateritium competes successfully for priming sites. A 3 : 1 ratio of sweetpotato DNA to $F$. lateritium DNA in PCR mixtures produced amplified DNA fragments specific to both species.

We have shown that PCR amplification using total DNA extracts from $F$. lateritiuminfected sweetpotato plants produce DNA fragments specific to the host and pathogen. Our results imply that other plant species may harbor pathogens that may produce DNA fragments that might confound analyses and interpretation.

\section{Literature Cited}

Clark, C.A., R.A. Valverde, J.A. Wilder-Ayers, and P.E. Nelson. 1990. Fusarium lateritium, causal agent of sweetpotato chlorotic leaf distortion. Phytopathology 80:741-744.

Jarret, R.L. and D.F. Austin. 1994. Genetic diversity and systematic relationships in sweetpotato (Ipomoea batatas L. Lam) and related species as revealed by RAPD analysis. Gent. Res. and Crop Evol. 41:165-169.

Jondle, R.J. 1992. Legal aspects of varietal protection using molecular markers, p. 50-52. In: Crop Sci. Soc. Amer./ASHS/Amer. Genet. Assn. Applications of RAPD technology to plant breeding. Joint Plant Breeding Symp. Ser., Minnesota.
Moyer, J.W., G.V.H. Jackson, and E.A. Friason. 1989. FAO/IBPGR technical guidelines for the safe movement of sweetpotato germplasm.FAO/ UN, IBPGR, Rome.

Paran, I., M. Horowitz, D. Zamir, and S. Wolf. 1995. Random amplified polymorphic DNA markers are useful for purity determination of tomato hybrids. HortScience 30:377.

Rongwen, J., M.S. Akkaya, A.A. Bhagwat, U. Lavi, and P.B. Cregan. 1995. The use of microsatellite DNA markers for soybean genotype identification. Theor. Appl. Genet. 90:43-48.

Saghai-Maroof, M.A., K.M. Soliman, R.A. Jorgenson, and R.W. Allard. 1984. Ribosomal DNA spacer-length polymorphisms in barley: Mendelian inheritance, chromosomal location, and populations dynamics. Proc. Natl. Acad. Sci. USA 81:8014-8018.

Villordon A.Q. and D.R. La Bonte. 1995. Variation in randomly amplified DNA markers and storage root yield in 'Jewel' sweetpotato clones. J. Amer. Soc. Hort. Sci. 120:734-740.

Wachira, F.N., R. Waugh, C.A. Hackett, and W. Powell. 1995. Detection of genetic diversity in tea (Camellia sinensis) using RAPD markers. Genome 38:201-210.

Weeden, N.F., G.M. Timmerman, M. Hemmat, B.E. Kneen, and M.A. Lodhi. 1992. Inheritance and reliability of RAPD markers, p.12-17. In: Crop Sci. Soc. Amer./ASHS/Amer. Genet. Assn. Applications of RAPD technology to plant breeding. Joint Plant Breeding Symposia Series, Minnesota.

Williams, J.G.K., M.K. Hanafey, J.A. Rafalski, and S.V. Tingely. 1993. Genetic analysis using random amplified polymorphic DNA markers, $\mathrm{p}$. 704-740. In: R. Wu (ed.). Methods in enzymology, Vol. 218, Academic, New York.

Yu, K.F., A.V. Deynze, and K.P. Pauls. 1993. Random amplified polymorphic DNA (RAPD) analysis, p. 287-301. In: B.R. Glick and J.E. Thompson (eds.).Methods in plant molecular biology and biotechnology. CRC Press, Boca Raton, Fla. 